\title{
Studies on leaf spot of chilli
}

\author{
DIPANKAR SARKAR, B.G. BARHATE* AND V.R. JOSHI
}

Department of Plant Pathology and Agricultural Microbiology, Mahatma Phule Krishi Vidyapeeth, Rahuri, AHMEDNAGAR (M.S.) INDIA

\section{ARITCLE INFO}

Received : 27.06 .2017

Revised : 27.08 .2017

Accepted : 09.09.2017

\section{KEY WORDS :}

Chilli, Leaf spot, Alternaria alternata, Biological control, Fungicides

*Corresponding author:

Email: :bgbarhate@gmail.com

\begin{abstract}
:
The leaf spot of chilli is important and destructive disease in chilli growing areas of Maharashtra, which is caused by Alternaria alternata. Therefore studies were undertaken at PGI, MPKV, Rahuri during the year 2016-17. For this leaves of chilli leaf spot were collected from the PGI farm MPKV Rahuri, which yielded the pathogen Alternaria alternata. The pathogenicity of Alternaria alternata was tested by Koch's postulates, which proved that the test pathogen was pathogenic to chilli. In vitro evaluation of effect of temperature and humidity revealed that test pathogen grew well with maximum sporulation at optimum temperature of $27^{\circ} \mathrm{C}$ with 80 per cent relative humidity. Six bioagents such as Trichoderma viride, Trichoderma harzianum, Trichoderma hamatum, Pseudomonas fluorescens, Bacillus subtilis and yeast (S. cerevisiae) were evaluated in vitro against isolated pathogen applying Dual Culture Technique. Among them T. harzianum was found most effective in inhibiting the growth of Alternaria alternata of about (76.23\%) this was followed by T. hamatum $(70.46 \%)$, yeast (S. cerevisiae) (57.98 \%), Bacillus subtilis (43.81\%), Pseudomonas fluorescens (36.01\%) and T. viride (34.81\%), respectively. Among the six botanicals leaf extracts (2\%) tested in vitro against the pathogen, Neem leaf extract was found most effective inhibiting $(55 \%)$ of the pathogen Alternaria alternata followed by garlic cloves $(41.25 \%)$, Tulsi leaf extract (36.25\%), nilgiri leaf extract (32.5\%), mixture of onion and garlic leaf extract (30\%) and parthenium (28.75\%) respectively. A total number of six fungicides viz., Carbendazim (0.05\%), Chlorothalonil ( $0.1 \%)$, Hexaconazole $(0.1 \%)$, Mancozeb $(0.1 \%)$, Propiconazole $(0.1 \%)$ and Captan $(0.1 \%)$ were evaluated in vitro against the isolated pathogen applying poison food technique. Among them Mancozeb @ $0.1 \%$, Carbendazim @ $0.05 \%$ and Captan @ 0.1\% recorded maximum growth inhibition of $78.99,78.66$ and 74.78 per cent, respectively of the test pathogen with minimum colony diameter of $17.33,17.66$ and $20.83 \mathrm{~mm}$, respectively.
\end{abstract}

How to view point the article : Sarkar, Dipankar, Barhate, B.G. and Joshi, V.R. (2017). Studies on leaf spot of chilli. Internat. J. Plant Protec., 10(2) : 369-374, DOI : 10.15740/HAS/IJPP/10.2/ 369-374.

spices, vegetable as well as commercial crop. Chilies are having good nutritious value and can be used as

\section{INTRODUCTION}

Chilli (Capsicum annuum L.) is an imperative 